\title{
Caesarean Section Birth Produces Long Term Changes in Dopamine D1 Receptors and in Stress-induced Regulation of D3 and D4 Receptors in the Rat Brain
}

\author{
Bassem El-Khodor, Ph.D. and Patricia Boksa, Ph.D.
}

Schizophrenia is associated with increased birth complications and altered mesocorticolimbic dopaminergic (DA) transmission, whereas stress also influences psychotic symptoms. Given this, the present study tested effects of two birth complications, Caesarean section (C-section) birth with or without acute global anoxia, on brain $D A$ receptors in rats at adulthood. Effects of repeated stress at adulthood were also tested. Before stress, C-sectioned rats showed increased D1-like receptor binding in limbic areas, compared to vaginally born controls. There were no differences between birth groups in D2-like, D3, or D4-like receptor binding before stress. After stress, $C$-sectioned animals showed decreased D3 receptors in accumbens and increased D4-like receptors in dorsal striatum, accumbens, and olfactory tubercles, compared to vaginal birth. This occurred because stress upregulated D3 receptors only with vaginal birth and upregulated D4-like receptors only with $C$-section. Animals born by C-section + anoxia showed no change in $D A$ receptors relative to vaginal birth, before or after stress. It is concluded that interactions between an individual's experience of stress at adulthood, together with other environmental events in their history, such as birth complications, can be important determinants of brain DA receptor levels.

[Neuropsychopharmacology 25:423-439, 2001] (C) 2001 American College of Neuropsychopharmacology. Published by Elsevier Science Inc.
KEY WORDS: Dopamine receptors; Perinatal; Hypoxia; Caesarean section; Schizophrenia; Neurodevelopment

The neurodevelopmental hypothesis of schizophrenia posits that psychotic symptoms in the young adult result from a complex interplay between early neurodevelopmental alterations, ongoing brain maturation and environmental factors such as stress, in susceptible in-

From the Departments of Psychiatry and of Neurology and Neurosurgery, McGill University, Douglas Hospital Research Center, Montreal, Quebec, Canada

Address correspondence to: P. Boksa, Ph.D., Douglas Hospital Research Center, 6875 LaSalle Blvd., Verdun, Quebec, Canada $\mathrm{H} 4 \mathrm{H} 1 \mathrm{R} 3$.

Received October 5, 2000; revised December 19, 2000; accepted January 3, 2001. dividuals (see reviews by Weinberger 1995; Walker et al. 1996; Benes 1997; Lieberman et al. 1997; Waddington et al. 1998). Among factors contributing to altered neurodevelopment, obstetric complications have been implicated. Numerous epidemiological studies have demonstrated increased obstetric complications, often involving perinatal hypoxia, among those who later develop schizophrenia. (e.g., Jones et al. 1998; Dalman et al. 1999; Geddes et al. 1999; Rosso et al. 2000; Zornberg et al. 2000; see review by McNeil 1995). This raises the question whether perinatal hypoxia can induce disruptions in key neurotransmitter systems implicated in schizophrenia, such as the dopamine (DA) system.

The involvement of DA in the pathophysiology of schizophrenia has attracted much attention since drugs that enhance dopaminergic transmission, like amphet- 
amine, exacerbate symptoms of schizophrenia and may, if abused, elicit a schizophrenia-like state in normal subjects (Laruelle et al. 1996; see review by Lieberman et al. 1997). Additionally, most antipsychotic medications block DA receptors and their affinities for the DA D2-like receptor correlate well with clinical potencies (Seeman 1992; see review by Sanyal and Van Tol 1997). More recently, in vivo imaging studies have demonstrated that amphetamine induces enhanced release of striatal DA in non-medicated schizophrenic subjects compared to controls (Laruelle et al. 1996, 1999; Breier et al. 1997). Moreover, postmortem and imaging studies have reported altered DA D1, D2, D3, and D4 receptor densities in schizophrenia (Knable et al. 1996; Goldsmith et al. 1997; Gurevich et al. 1997; Marzella et al. 1997; Okubo et al. 1997; Lahti et al. 1998a; Laruelle 1998; see review by Sanyal and Van Tol 1997).

Given these findings in schizophrenia, several studies have used a rat model of global anoxia during Caesarean section (C-section) birth to directly test if birth hypoxia alters later dopaminergic function and its responsiveness to stress (Bjelke et al. 1991; Loidl et al. 1994; Brake et al. 1997a,b; Chen et al. 1995, 1997a; ElKhodor and Boksa 1997, 1998; Vaillancourt and Boksa 1998). These studies demonstrated that repeated stressinduced DA release from nucleus accumbens (NAcc) and amphetamine-induced behavioral responses are enhanced in adult rats that had been born by C-section, either with or without addition of 15 min of global anoxia, compared to vaginally born controls (Brake et al. 1997b; El-Khodor and Boksa 1998). Thus C-section birth is sufficient perturbation to alter dopaminergic responses to stress and amphetamine in rats. In the rat model used, both C-section birth and C-section with added global anoxia appear to produce perinatal hypoxia but with two distinct profiles. C-section birth produces respiratory alterations and very low grade CNS hypoxia during the first $24 \mathrm{~h}$ of life in the rat (El-Khodor and Boksa 1997; Vaillancourt et al. 1999), similar to the reported increased incidence of mild respiratory distress in humans born by C-section (Hales et al. 1993).

Pups undergoing a short period (5-15 min) of global anoxia during $\mathrm{C}$-section birth actually show more rapid and lasting respiratory adaptation than do pups born by C-section alone (El-Khodor and Boksa 1997; Vaillancourt et al. 1999; Berger et al. 2000), due to hormonal and respiratory compensatory responses to the acute anoxic insult. This raises the possibility that $\mathrm{C}$-section birth and C-section birth with added anoxia might differ in their long term effects on specific biochemical components related to dopaminergic transmission. In fact, adult rats born by C-section show altered steady state levels of DA in various brain regions compared to vaginal birth while these changes are not observed in animals born by $\mathrm{C}$-section with 15 min of added global anoxia (El-Khodor and Boksa 1997).
The current study considered whether the dysregulation of dopaminergic function following C-section birth or C-section birth with global anoxia also includes alteration in DA receptors. DA receptors are divided into two families: the D1-like including D1 and D5 receptors and the D2-like including D2, D3, and D4 receptors, with both families widely distributed in striatal, cortical, and limbic DA terminal regions (Lachowicz and Sibley 1997). D2 receptors, and possibly also D3 receptors, regulate presynaptic DA release (Wolf and Roth 1990; Rivet et al. 1994; Tang et al. 1994), whereas D1-like, D2, and D3 receptors modulate mesolimbic DA-mediated behavioral responses like locomotion (Braun and Chase 1986; Dreher and Jackson 1989; Accili et al. 1996; De Boer et al. 1997). Moreover, stress can alter brain DA receptor responsivity (see review by Puglisi-Allegra and Cabib 1997). However few studies have assessed stress-induced changes in DA receptor densities in animal models (Papp et al. 1994; Pothos et al. 1995; Cabib et al. 1998; Giardino et al. 1998) and none have investigated whether stress-induced modulation of DA receptors is altered by birth insult.

Given this background, this study had three aims: 1) to test if C-section birth or C-section birth with global anoxia, produce long-term changes in DA D1-like, D2like, D3, or D4-like receptors in limbic and striatal brain areas, compared to vaginal birth, in the rat; 2) to test if repeated stress administered to adult rats alters DA receptors; and 3) to test if repeated stress alters DA receptors differentially in adult rats that had been born vaginally, by C-section or by C-section with global anoxia.

\section{METHODS}

\section{Materials}

[3H]-SCH-23390 and [3H]-YM-09151-2 were purchased from DuPont New England Nuclear (Boston, Massachusetts, USA). [3H]-7-hydroxy-dipropylaminotetralin ([3H]7-OH-DPAT), [3H]-Hyperfilm and microscale-calibrated tritium standards were from Amersham Canada (Toronto, Ontario, Canada). (+)-Butaclamol, 8-hydroxy-dipropylaminotetralin (8-OH-DPAT), guanosine triphosphate (GTP), ketanserin, raclopride and DA were obtained from RBI / Sigma (Oakville, Ontario, Canada) and 1,3di(2-5-tolyl)guanidine (DTG) was from Sigma Aldrich Canada Ltd. (Oakville, Ontario, Canada).

\section{Experimental Design}

All procedures with animals were performed in accordance with guidelines from the Canadian Council on Animal Care and were approved by the McGill University Animal Care Committee.

Sprague-Dawley rats were born by one of the three birth procedures outlined below and grown to adult- 
hood. At four months of age, one half of the animals in each birth group received tail pinch stress on each of five consecutive days, and all animals were sacrificed two weeks later for measurement of DA receptors.

\section{Birth Conditions: C-section + Anoxia; C-section; Vaginal Birth}

For all birth conditions, timed pregnant rat dams (Charles River, St. Constant, Quebec, Canada) at 22 days of gestation (i.e., the expected day of delivery) were used. Pups in each birth group (vaginal birth, C-section, C-section + anoxia) were born from at least four different dams. To avoid possible prematurity, C-sections were only begun after one of a group of timed pregnant dams, mated at the same time, had given birth vaginally and only pups from litters with all members weighing $>5 \mathrm{~g}$ at delivery were used. Only male offspring were retained for study.

Rat pups were subjected to acute global anoxia during C-section birth using procedures modified from Bjelke et al. (1991) and previously described by our laboratory (El-Khodor and Boksa 1997, 1998). Briefly, at 22 days of gestation, pregnant rats were decapitated, an abdominal incision was made and the uterus was quickly isolated from its blood supply and surrounding connective tissue (10-15 sec). (Dams were killed by decapitation to avoid the confound of anesthetic use.) An acute anoxic episode was induced by immersing the intact uterus into a $37^{\circ} \mathrm{C}$ saline bath for $15 \mathrm{~min}$ (C-section + anoxia group). The pups were then delivered and stimulated by gentle tapping until breathing became even (30-40 sec). No other means of artificial resuscitation was employed. The umbilical cord was ligated and the animals placed on a heating pad until given to their surrogate mothers (1-2 hr). Survival was $90-95 \%$ following 15 min of birth anoxia. [In general, the immature central nervous system (CNS) of any species can sustain longer periods of hypoxia than does the adult and the rat is able to sustain longer periods of hypoxia at birth than does the human neonate (Jilek et al. 1970). Rats subjected to $15 \mathrm{~min}$ (or up to $20 \mathrm{~min}$ ) of anoxia during $\mathrm{C}$-section begin breathing at birth without artificial resuscitation other than palpation. Presumably if vigorous artificial ventilation and resuscitation procedures were employed rat pups might survive even longer periods of birth hypoxia; thus $15 \mathrm{~min}$ of hypoxia may be considered a "moderate" hypoxic episode in the neonatal rat. Recent results quantitating brain lactate, a marker of CNS hypoxia, and brain adenosine triphosphate (ATP) during the first $24 \mathrm{~h}$ of life, indicate that this model produces consistent and reproducible CNS hypoxia in offspring (El-Khodor and Boksa 1997; Berger et al. 2000)].

A second group of animals was delivered via C-section with no period of added anoxia in the saline bath (C-section group). Time between sacrifice of the dam and delivery of the last pup in a litter for the C-section group was $<1.5 \mathrm{~min}$ and survival was $100 \%$ in the C-section group. Pups born vaginally served as controls (vaginal birth group). Vaginally born animals were removed from their dams at $0-12 \mathrm{~h}$ after birth and were placed on a heating pad for $1-2 \mathrm{~h}$ before being placed with surrogate dams. Pups from all three groups were cross-fostered by surrogate dams in mixed litters (12 pups/dam) to minimize differential rearing effects. Animals were weaned at 21 days of age and grown to adulthood (four months), group housed (three animals/cage) in random combinations of vaginally born, $\mathrm{C}$-sectioned and anoxic animals and maintained on a 12h:12h light:dark schedule with free access to food and water.

\section{Repeated Stress at Adulthood}

Repeated stress was administered to one half of the animals in each birth group as follows. At four months of age, rats born vaginally, by C-section or by C-section + $15 \mathrm{~min}$ anoxia received $15 \mathrm{~min}$ of tail pinch stress / day for five consecutive days. On each stress day, the animal was removed from its home cage, placed singly in a holding cage and left untouched for $10 \mathrm{~min}$. Following this, tail pinch was administered by placing a plastic clothes pin approximately $1 \mathrm{~cm}$ from the base of the tail for $15 \mathrm{~min}$. Animals were always stressed in the same room and at the same time of day (from 9:00 a.m. to 12:00 p.m.). After completion of the stress session, the animal was returned to its original home cage (three rats/cage).

Non-stressed animals received no tail pinch stress but were handled as follows. At four months of age, rats born vaginally, by $\mathrm{C}$-section or by $\mathrm{C}$-section +15 min anoxia were placed singly in holding cages and left untouched for $25 \mathrm{~min} /$ day for five consecutive days. The animal was then returned to its home cage. The non-stressed animals were never in the same room with the stress group during a stress session. All animals were sacrificed two weeks after the last stress or handling session. Two weeks after stress was chosen as it has been suggested that only biochemical changes persisting for at least two weeks may be considered of potential relevance to the lasting behavioral sensitization that can be produced by repeated stress or psychostimulant administration (Kalivas and Stewart 1991; Pierce and Kalivas 1997).

\section{Receptor Autoradiography}

Receptor autoradiography was performed as described by Flores et al. (1996b) and, for D3 receptors by Lévesque et al. (1992), with minor modifications. Brains were rapidly isolated, frozen in isopentane $\left(-40^{\circ} \mathrm{C}\right)$ and stored at $-80^{\circ} \mathrm{C}$ until use. Coronal sections (15 $\mu \mathrm{m}$ 
thickness, cut in a cryostat at $-20^{\circ} \mathrm{C}$ ) were mounted on cleaned gelatin-coated microscope slides, dessicated under vacuum at $4^{\circ} \mathrm{C}$ overnight and stored at $-80^{\circ} \mathrm{C}$ until the day of the experiment. Sections were selected for analysis using the rat brain atlas of Paxinos and Watson (1986). For D3 receptor binding, the dorsal striatum (caudate putamen), NAcc (ventral striatum), olfactory tubercles and islands of Calleja were analyzed at $+1.6 \mathrm{~mm}$ to bregma, to maximize visualization of the islands of Calleja which contain the highest CNS levels of D3 receptors. For all other DA receptors, these areas were analyzed at +1.2 to $+0.7 \mathrm{~mm}$ to bregma. Sections at +3.2 to $+2.7 \mathrm{~mm}$ to bregma were used to analyze D1 receptors in cingulate and infralimbic cortices, anteromedial, suprarhinal, and lateral regions of frontal cortex, anterior olfactory nucleus, and tenia tecta, which are all DA terminal regions containing appreciable numbers of D1 receptors (Dawson et al. 1986).

For D1-like receptor binding, sections were preincubated for $10 \mathrm{~min}$ at room temperature in buffer containing $50 \mathrm{mM}$ Tris- $\mathrm{HCl}, 154 \mathrm{mM} \mathrm{NaCl}, 1 \mathrm{mM}$ ethylenediaminetetraacetic acid (EDTA), and $0.1 \%$ bovine serum albumin, with $\mathrm{pH}$ adjusted to 7.4. Sections were then incubated for $90 \mathrm{~min}$ at room temperature in the same buffer containing $2 \mathrm{nM}[3 \mathrm{H}]-\mathrm{SCH}-23390(83 \mathrm{Ci} / \mathrm{mmol})$ and $30 \mathrm{nM}$ ketanserin (to block serotonergic 5-HT2 sites). Nonspecific binding was determined on adjacent sections using $1 \mu \mathrm{M}(+)$-butaclamol. Following incubation, slides were dipped in buffer $\left(4^{\circ} \mathrm{C}, \mathrm{pH}\right.$ 7.4) followed by two consecutive 10 min washes in the same buffer, dipped in ice-cold distilled water, dried in a stream of cold air for $30 \mathrm{~min}$ and left at room temperature overnight. Slides were then apposed to $[3 \mathrm{H}]-$ Hyperfilm for six days for dorsal striatal/NAcc sections and for 15 days for frontal/cingulate/infralimbic cortex sections, alongside high activity microscale-calibrated tritium standards.

For D2-like and D4-like receptor binding, sections were preincubated for $10 \mathrm{~min}$ at room temperature in buffer containing $50 \mathrm{mM}$ Tris- $\mathrm{HCl}, 120 \mathrm{mM} \mathrm{NaCl}, 1 \mathrm{mM}$ EDTA, $5 \mathrm{mM} \mathrm{KCl}, 1.5 \mathrm{mM} \mathrm{CaCl} 2$, and $4 \mathrm{mM} \mathrm{MgCl} 2$, with $\mathrm{pH}$ adjusted to 7.4. Sections were then incubated for $2 \mathrm{~h}$ at room temperature in the same buffer containing $1 \mathrm{nM} \mathrm{[3H]-YM-09151-2} \mathrm{(85.5} \mathrm{Ci/mmol)} \mathrm{and} 50 \mathrm{nM}$ 8-OH-DPAT (to block serotonergic 5-HT1A sites), with or without $100 \mathrm{nM}$ raclopride, for assessment of $\mathrm{D} 4$ and D2 receptor binding, respectively. Nonspecific binding was determined on adjacent sections using $1 \mu \mathrm{M}(+)-$ butaclamol. Following incubation, sections were washed in ice-cold buffer, then water, and were dried as described above for D1-like binding. Slides were then apposed to [3H]-Hyperfilm for 16 days alongside high activity tritium standards.

For D3 receptor binding, sections were preincubated for $30 \mathrm{~min}$ at room temperature in buffer containing 50 $\mathrm{mM}$ Tris- $\mathrm{HCl}, 100 \mathrm{mM} \mathrm{NaCl}$, and $300 \mu \mathrm{M}$ GTP, with
$\mathrm{pH}$ adjusted to 7.4. Sections were then incubated for $2 \mathrm{~h}$ at room temperature in the same buffer containing 2 $\mathrm{nM}[3 \mathrm{H}]-7-\mathrm{OH}-\mathrm{DPAT}(151 \mathrm{Ci} / \mathrm{mmol})$ and $5 \mu \mathrm{M}$ DTG (to block binding to sigma sites). Nonspecific binding was determined on adjacent sections using $1 \mu \mathrm{M}$ DA. Following incubation, sections were washed twice for 10 min each with buffer consisting of $50 \mathrm{mM}$ Tris- $\mathrm{HCl}$ $\left(4^{\circ} \mathrm{C}, \mathrm{pH} 7.4\right)$, dipped in ice-cold water, dried and apposed to $[3 \mathrm{H}]$-Hyperfilm for eight weeks alongside high activity tritium standards.

For each DA receptor subtype, slides for total and nonspecific binding from the three birth groups (i.e., vaginal birth, $\mathrm{C}$-section, $\mathrm{C}$-section + anoxia), with or without stress, were always exposed on the same film to minimize error associated with film exposure and development.

[3H]-SCH-23390 labels both members of the D1-like receptor family, i.e., D1 and D5 receptors, whereas [3H]-YM-09151-2 labels the three members of the D2like receptor family, i.e., D2, D3, and D4 receptors. Consistent with labelling of D3 receptors reported by others (Lévesque et al. 1992; Demotes-Mainard et al. 1996), [3H]-7-OH-DPAT binding under the above described conditions, was low in dorsal striatum, higher in NAcc shell compared to core and highest in the islands of Calleja (see Figures 2 and 4). The low binding of [3H]-7$\mathrm{OH}-\mathrm{DPAT}$ in the dorsal striatum indicates that the ligand labelled D3 and not D2 receptors, which are highly concentrated in dorsal striatum. [3H]-YM-091512 in the presence of $100 \mathrm{nM}$ raclopride (high affinity for D2 and D3 receptors) labels a subpopulation of the D2like receptors that have been designated D4-like (Sanyal and Van Tol 1997) but may include a larger subpopulation of sites than the molecularly defined D4 receptor (Primus et al. 1997; Tarazi et al. 1997).

\section{Data Analysis}

Computerized image analysis (MCDI-4, Imaging Research, Saint Catherines, Ontario, Canada) was used to analyze the autoradiograms. Binding was analyzed in the right and left hemispheres of various brain regions identified according to Paxinos and Watson (1986). For each brain region, three sections measuring total binding and three sections measuring non-specific binding were analyzed for each animal; means of the values from the three "total binding" sections were used for total binding for that animal and similarly for non-specific binding. The $3 \mathrm{H}$ microscale standards used for the autoradiography are calibrated for the auto-absorptive features of intact brain grey matter, to produce a standard curve in which optical density is converted to $\mathrm{nCi}$ radioligand / $\mathrm{mg}$ tissue. Thus data are expressed as $\mathrm{fmol}$ specific binding $/ \mathrm{mg}$ tissue $\pm \mathrm{SEM}$, for the number of animals indicated in each figure legend. For all brain 
Table 1. Summary of Selected Comparisons for D1-like Receptor Binding Obtained by Three-Way ANOVA (a) or By TwoWay ANOVA (b)

\begin{tabular}{|c|c|c|c|}
\hline & Birth Group & Stress & Birth Group $\times$ Stress \\
\hline \multicolumn{4}{|l|}{ (a) } \\
\hline Lat Fr cx & $\left(\mathrm{F}_{2,42}=3.37, p=.0440\right)^{*}$ & $\left(\mathrm{~F}_{1,42}=11.06, p=.0018\right)^{*}$ & $\left(\mathrm{~F}_{2,42}=0.91, p=.4114\right)$ \\
\hline $\mathrm{AM}+\mathrm{SR} c x$ & $\left(\mathrm{~F}_{2,49}=2.36, p=.1052\right)$ & $\left(\mathrm{F}_{1,49}=0.61, p=.4373\right)$ & $\left(\mathrm{F}_{2,49}=1.43, p=.2485\right)$ \\
\hline $\mathrm{AON}+\mathrm{TT}$ & $\left(\mathrm{F}_{2,47}=5.18, p=.0093\right)^{*}$ & $\left(\mathrm{~F}_{1,47}=7.75, p=.0077\right)^{*}$ & $\left(\mathrm{~F}_{2,47}=3.70, p=.0323\right)^{*}$ \\
\hline Dorsal Striatum & $\left(\mathrm{F}_{2,50}=2.15, p=.1276\right)$ & $\left(\mathrm{F}_{1,50}=0.38, p=.5403\right)$ & $\left(\mathrm{F}_{2,50}=1.04, p=.3599\right)$ \\
\hline NAcc-Shell & $\left(\mathrm{F}_{2,48}=3.63, p=.0339\right)^{*}$ & $\left(\mathrm{~F}_{1,48}=1.81, p=.1854\right)$ & $\left(\mathrm{F}_{2,48}=2.05, p=.1401\right)$ \\
\hline NAcc-Core & $\left(\mathrm{F}_{2,48}=4.08, p=.0231\right)^{*}$ & $\left(\mathrm{~F}_{1,48}=1.29, p=.2624\right)$ & $\left(\mathrm{F}_{2,48}=2.35, p=.1065\right)$ \\
\hline OT & $\left(\mathrm{F}_{2,45}=6.90, p=.0024\right)^{*}$ & $\left(\mathrm{~F}_{1,45}=0.06, p=.8066\right)$ & $\left(\mathrm{F}_{2,45}=1.61, p=.2107\right)$ \\
\hline NAcc-Shell & $\begin{array}{c}\text { Hemisphere } \\
\left(\mathrm{F}_{2,48}=10.29, \mathrm{p}=0.0024\right)^{*}\end{array}$ & $\begin{array}{l}\text { Birth Group } \times \text { Hemisphere } \\
\quad\left(\mathrm{F}_{1,48}=0.57, \mathrm{p}=0.5679\right)\end{array}$ & $\begin{array}{c}\text { Hemisphere } \times \text { Stress } \\
\left(\mathrm{F}_{2,48}=1.28, \mathrm{p}=0.2631\right)\end{array}$ \\
\hline \multicolumn{4}{|l|}{ (b) } \\
\hline & Birth group & Stress & Birth group $\times$ stress \\
\hline $\mathrm{Cg} c \mathrm{c}$ & $\left(\mathrm{F}_{2,48}=1.92, p=.1581\right)$ & $\left(\mathrm{F}_{2,48}=9.66, p=.0032\right)^{*}$ & $\left(\mathrm{~F}_{2,48}=0.11, p=.8936\right)$ \\
\hline Il cx & $\left(\mathrm{F}_{2,50}=2.56, p=.0875\right)$ & $\left(\mathrm{F}_{2,50}=5.63, p=.0216\right)^{*}$ & $\left(\mathrm{~F}_{2,50}=3.34, p=.0435\right)^{*}$ \\
\hline \multicolumn{4}{|c|}{$\begin{array}{l}\text { For (a), birth group and stress were analyzed as independent factors with brain hemisphere as correlated factor. For effects of hemisphere or inter- } \\
\text { actions with hemisphere, only values for the one brain region in which significance was detected are shown. For (b), birth group and stress were ana- } \\
\text { lyzed as independent factors; midline brain regions }(\mathrm{Cg} c x ; \mathrm{ILcx} \text { ) were not separated into left and right structures but were analyzed as single entities. } \\
\text { Abbreviations used: Lat Fr cx, lateral frontal cortex; } \mathrm{AM}+\mathrm{SR} \mathrm{cx} \text {, anteromedial and suprarhinal regions of frontal cortex; AON + TT, anterior olfac- } \\
\text { tory nucleus + tenia tecta; NAcc, nucleus accumbens; OT, olfactory tubercle; } \mathrm{Cg} \text { cx, cingulate cortex; IL cx, infralimbic cortex. } \\
\text { *F value significant at } p<05\end{array}$} \\
\hline
\end{tabular}

regions except the cingulate and infralimbic cortices, statistical comparisons were performed using threeway analyses of variance (ANOVA) with birth group and stress as independent factors and hemisphere as correlated factor. For the cingulate and infralimbic cortices, two midline brain regions which were not separated into left and right structures, two-way ANOVA were performed with birth group and stress as independent factors. ANOVA were followed by simple main effects and post-hoc Newman-Keuls tests where indicated; $p<.05$ was considered significant.

\section{RESULTS}

D1-like ([3H]-SCH-23390), D2-like ([3H]-YM-09151-2), D3 ([3H]-7-OH-DPAT), and D4-like ([3H]-YM-09151-2 + raclopride) receptor binding were quantitated in the

Table 2. Summary of Selected Comparisons for D2-like, D3, and D4-like Receptor Levels Obtained by Three-way ANOVA

\begin{tabular}{llll}
\hline & Birth Group & Stress & Birth Group $\times$ Stress \\
\hline D2-like & & & \\
$\quad$ Dorsal Striatum & $\left(\mathrm{F}_{2,46}=0.23, p=.7980\right)$ & $\left(\mathrm{F}_{1,50}=0.74, p=.3943\right)$ & $\left(\mathrm{F}_{2,50}=0.89, p=.4193\right)$ \\
NAcc-Shell & $\left(\mathrm{F}_{2,45}=2.62, p=.0840\right)$ & $\left(\mathrm{F}_{1,45}=9.02, p=.0043\right)^{*}$ & $\left(\mathrm{~F}_{2,45}=2.64, p=.0823\right)$ \\
NAcc-Core & $\left(\mathrm{F}_{2,45}=0.99, p=.3793\right)$ & $\left(\mathrm{F}_{1,45}=3.79, p=.0578\right)$ & $\left(\mathrm{F}_{2,45}=2.32, p=.1100\right)$ \\
OT & $\left(\mathrm{F}_{2,41}=1.38, p=.2620\right)$ & $\left(\mathrm{F}_{1,41}=0.76, p=.3897\right)$ & $\left(\mathrm{F}_{2,41}=0.34, p=.7133\right)$ \\
D3 & & & $\left(\mathrm{F}_{1,36}=2.86, p=.0993\right)$ \\
Dorsal Striatum & $\left(\mathrm{F}_{2,36}=0.76, p=.4755\right)$ & $\left(\mathrm{F}_{1,48}=0.30, p=.5863\right)$ & $\left(\mathrm{F}_{2,36}=3.13, p=.0559\right)$ \\
NAcc-Shell & $\left(\mathrm{F}_{2,48}=3.21, p=.0491\right)^{*}$ & $\left(\mathrm{~F}_{1,48}=1.79, p=.1870\right)$ & $\left(\mathrm{F}_{2,48}=4.02, p=.0243\right)^{*}$ \\
NAcc-Core & $\left(\mathrm{F}_{2,48}=7.48, p=.0015\right)^{*}$ & $\left(\mathrm{~F}_{1,47}=6.58, p=.0136\right)^{*}$ & $\left(\mathrm{~F}_{2,48}=2.56, p=.0878\right)$ \\
Isl. Calleja & $\left(\mathrm{F}_{2,47}=1.32, p=.2757\right)$ & $\left(\mathrm{F}_{1,48}=4.77, p=.0339\right)^{*}$ & $\left(\mathrm{~F}_{2,47}=0.58, p=.5627\right)$ \\
OT & $\left(\mathrm{F}_{2,48}=1.42, p=.2528\right)$ & $\left(\mathrm{F}_{2,48}=3.94, p=.0261\right)^{*}$ \\
D4-like & & $\left(\mathrm{F}_{1,48}=0.66, p=.4193\right)$ & $\left(\mathrm{F}_{2,48}=9.30, p=.0004\right)^{*}$ \\
Dorsal Striatum & $\left(\mathrm{F}_{2,48}=2.96, p=.0613\right)$ & $\left(\mathrm{F}_{1,47}=8.66, p=.0050\right)^{*}$ & $\left(\mathrm{~F}_{2,47}=6.44, p=.0034\right)^{*}$ \\
NAcc-Shell & $\left(\mathrm{F}_{2,47}=8.69, p=.0006\right)^{*}$ & $\left(\mathrm{~F}_{1,47}=7.28, p=.0096\right)^{*}$ & $\left(\mathrm{~F}_{2,47}=9.23, p=.0004\right)^{*}$ \\
NAcc-Core & $\left(\mathrm{F}_{2,47}=4.73, p=.0134\right)^{*}$ & $\left(\mathrm{~F}_{1,44}=1.54, p=.2213\right)$ & $\left(\mathrm{F}_{2,44}=3.61, p=.0353\right)^{*}$ \\
OT & $\left(\mathrm{F}_{2,44}=6.84, p=.0026\right)^{*}$ & &
\end{tabular}

Birth group and stress were analyzed as independent factors with brain hemisphere as correlated factor. There were no significant effects of hemisphere or interactions with hemisphere, thus values for these comparisons are not shown. Abbreviations: NAcc, nucleus accumbens; OT, olfactory tubercle; Isl. Calleja, islands of Calleja.

${ }^{*} \mathrm{~F}$ value significant at $p<.05$. 

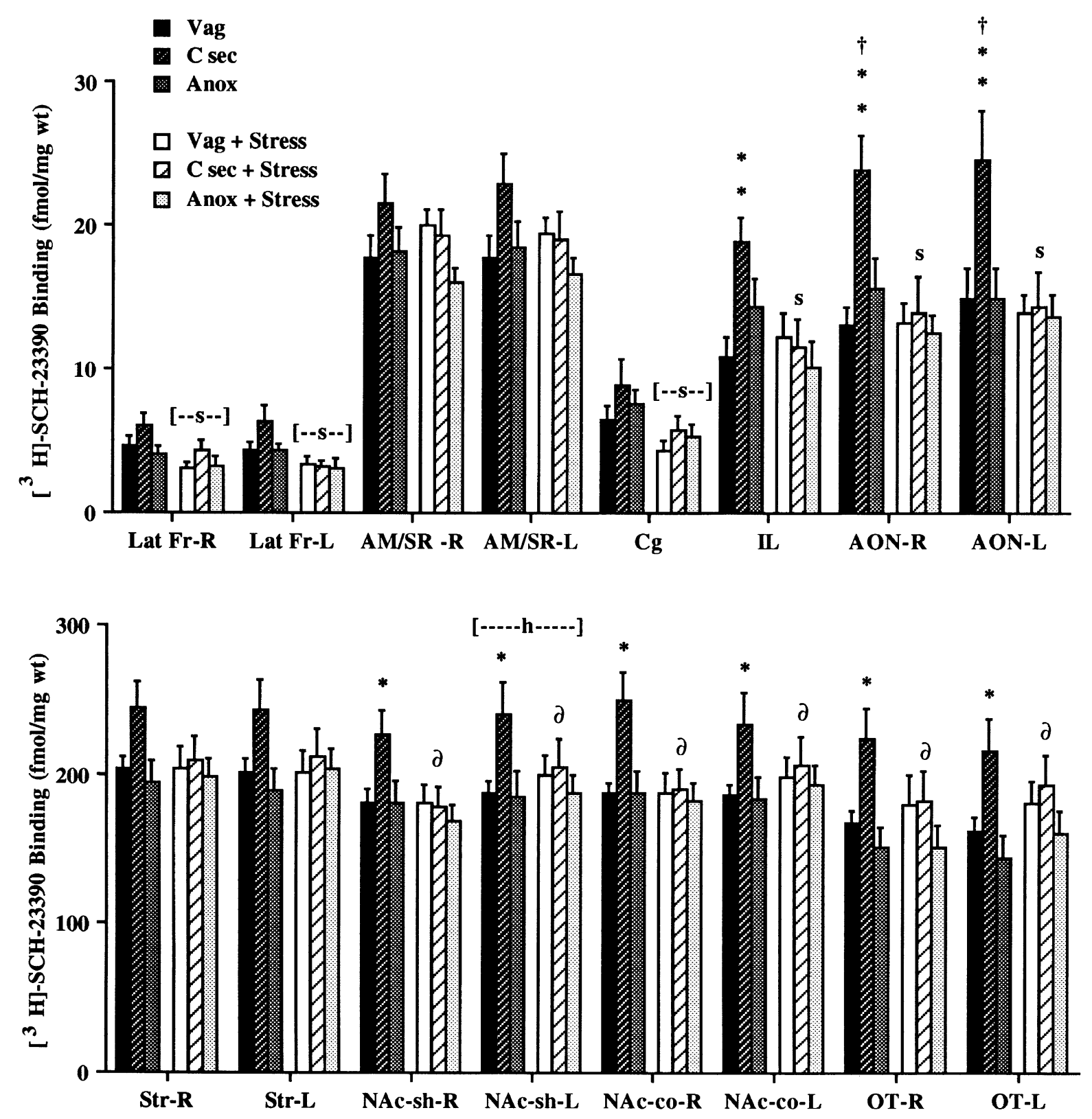

Figure 1. Quantitative autoradiographic assessment of D1-like DA receptors ([3H]-SCH-23390) in brain regions of nonstressed and stressed adult rats, that had been born vaginally, by C-section or by C-section +15 min anoxia. Specific [3H]SCH-23390 binding is expressed in fmol/mg tissue in subregions of brain defined according to Paxinos and Watson (1986). Values shown represent the mean specific binding \pm SEM from the number of animals in parentheses as follows: Vag (6-8); C sec (8-10); Anox (8-10); Vag + Stress (7-10); C sec + Stress (6-10); Anox + Stress (8-10). Note the different scales for the $y$ axes in the upper and lower graphs. Abbreviations: Vag, vaginal birth; C sec, C-section birth; Anox, C-section +15 min of anoxia; Lat Fr, lateral frontal cortex; $\mathrm{AM} / \mathrm{SR}$, anteromedial and suprarhinal regions of frontal cortex; $\mathrm{Cg}$, cingulate cortex; IL, infralimbic cortex; AON, anterior olfactory nucleus + tenia tecta; Str, dorsal striatum; NAc-sh, nucleus accumbens shell; NAc-co, nucleus accumbens core; OT, olfactory tubercle; R, right hemisphere; L, left hemisphere. [-s-] = different from the corresponding birth group with no stress at $p<.005$, due to main effect of stress across all birth groups; ${ }^{* *}$ different from Vag at $p<.01 ;{ }^{\dagger}$ different from Anox at $p<.01 ;{ }^{\mathrm{s}}=$ different from C sec (no stress) at $p<.005 ;{ }^{*}$ different from both Vag and Anox at $p<.05$, due to main effect of birth group across stress/no stress; $\delta=$ different from both Vag + Stress and Anox + Stress at $p<.05$, due to main effect of birth group across stress/no stress, [- $\mathrm{h}-$ - ] = different from right hemisphere of the corresponding birth group at $p<.005$, due to main effect of hemisphere across all birth groups. 


\section{a) D1-like receptors - no stress}

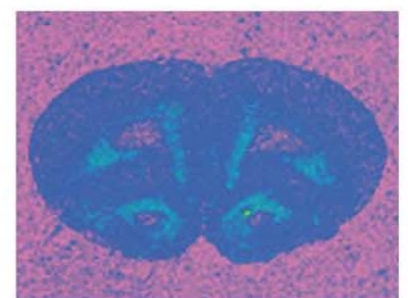

Vaginal birth

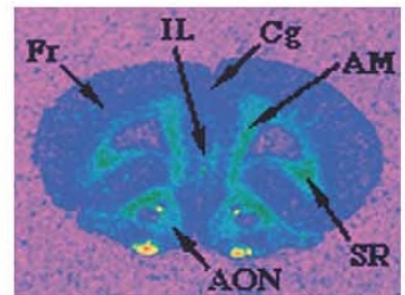

C.section

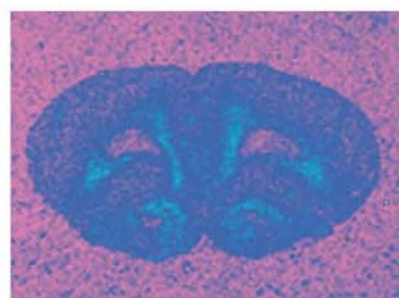

C-section + anoxia

\section{b) D1-like receptors - no stress}

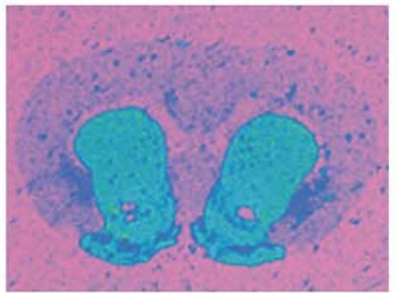

Vaginal birth

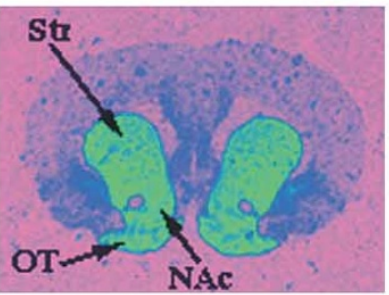

C-section

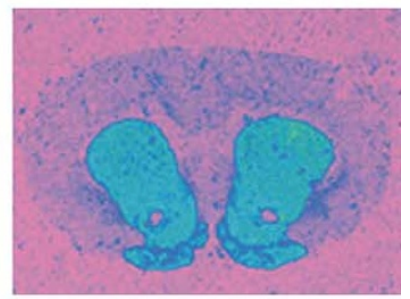

C-section + anoxia

c) D3 receptors - after stress

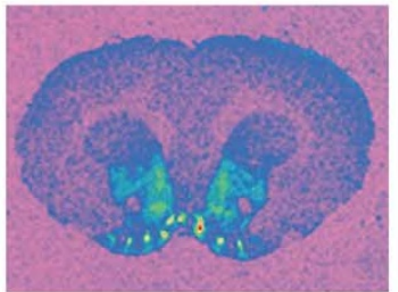

Vaginal birth

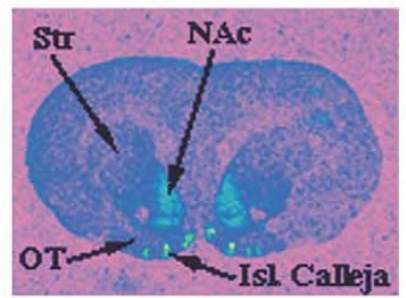

C-section

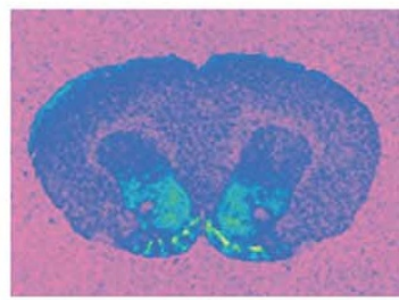

C-section + anoxia

d) D4-like receptors - after stress

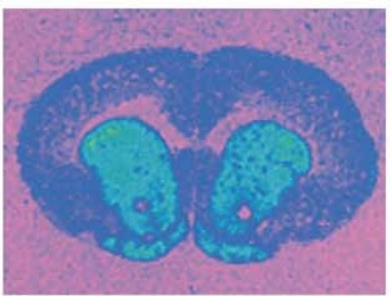

Vaginal birth

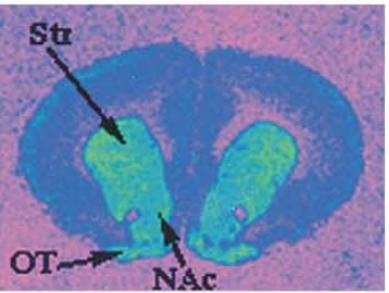

C-section

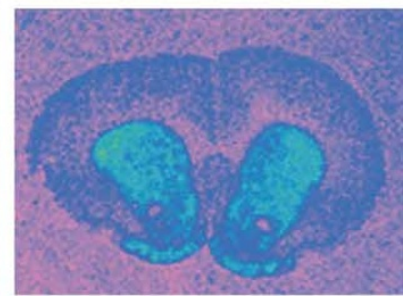

C-section + anoxia

Figure 2. Autoradiographic visualization of DA receptors in brain regions of adult rats, that had been born vaginally, by C-section or by C-section +15 min anoxia. Panels $\boldsymbol{a}$ and $\boldsymbol{b}$ show D1-like DA receptors ([3H]-SCH-23390) at the level of frontal/cingulate/infralimbic cortices (a) or dorsal striatum/nucleus accumbens (b) from non-stressed adult rats. Panels $c$ and $d$ show D3 DA receptors ([3H]-7-OH-DPAT) (c) and D4-like DA receptors ([3H]-YM-09151-2 + raclopride) (d) at the level of dorsal striatum/nucleus accumbens from rats repeatedly stressed as adults. The autoradiograms show total binding. However, since there were no birth group differences in non-specific binding, the autoradiograms are illustrative of group differences in specific binding. (See Figures 1 and 3-5 for quantitation of changes in specific binding). Without stress, C-sectioned animals showed increased D1-like receptor binding in infralimbic cortex, anterior olfactory nucleus + tenia tecta region, nucleus accumbens shell and core, and olfactory tubercles, compared to vaginal birth. After stress, C-sectioned animals showed decreased D3 receptor binding in nucleus accumbens shell and core compared to vaginal birth, and increased D4like receptor binding in dorsal striatum, nucleus accumbens shell and core, and olfactory tubercles, compared to vaginal birth. Abbreviations: Fr, lateral frontal cortex; IL, infralimbic cortex; Cg, cingulate cortex; AM, anteromedial region of frontal cortex; SR, suprarhinal region of frontal cortex; AON, anterior olfactory nucleus + tenia tecta; Str, dorsal striatum; NAc, nucleus accumbens; OT, olfactory tubercle; Isl. Calleja, islands of Calleja. 
right and left hemispheres of various brain regions of adult rats that had been born vaginally, by C-section or by C-section +15 min of global anoxia. Receptor binding was quantitated in groups of animals under baseline, non-stressed conditions, and in separate groups of animals that were repeatedly stressed as adults $(15 \mathrm{~min}$ tail pinch daily for five days). Summaries of $\mathrm{F}$ and $p$ values obtained by ANOVA of data for D1-like receptor binding are shown in Table 1 and for D2-like, D3, and D4-like receptor binding in Table 2.

\section{Effects of Hemisphere}

Left-right hemispheric differences in dopaminergic biochemistry and function, including responses to stress, have been previously reported (Sullivan and Gratton 1998). We, thus, separately analyzed DA receptor binding in right and left hemispheres of various brain regions. With the exception of D1-like receptors in the NAcc shell, no significant effects of hemisphere were found for D1like, D2-like, D3, or D4-like receptor binding in any brain region analyzed and no significant interactions of hemisphere with birth group or with stress were observed (Tables 1 and 2). A significant main effect of hemisphere was found for D1-like receptors in the NAcc shell. D1-like receptor binding was increased in the left NAcc shell relative to the right in all birth groups, both before and after stress (Figure 1). All further results described below apply to both left and right hemispheres.

\section{Birth Group Differences before Stress}

Under baseline conditions without stress, there was an increase in the C-section group in D1-like receptor binding in the infralimbic cortex and anterior olfactory nucleus, as well as in the NAcc shell and core and olfactory tubercles (Figures 1, 2a, and 2b), relative to vaginal birth. In the latter three brain regions, there was a main effect of birth group across stress/no stress, however the most prominent increase in D1-like receptors in the C-section group was observed before stress. Although there were tendencies to increased D1-like receptors in additional regions (lateral frontal cortex, anteromedial and suprarhinal regions of frontal cortex, dorsal striatum) in the C-sectioned compared to vaginally born groups before stress, these differences did not reach statistical significance.

There were no differences between birth groups in D2like, D3, or D4-like receptor binding before stress (Figures 3-5), with the exception of a slight decrease in D3 receptor binding in the NAcc core of C-sectioned animals compared to vaginal birth (Figure 4). However this slight decrease in D3 reached significance due to a main effect of birth group across stress/no stress with the major birth group differences in this receptor occurring after stress.

\section{Effects of Stress and Resulting Birth Group Differences after Stress: D1-like Receptors}

Repeated stress decreased D1-like receptor binding in lateral frontal and cingulate cortices of all three birth

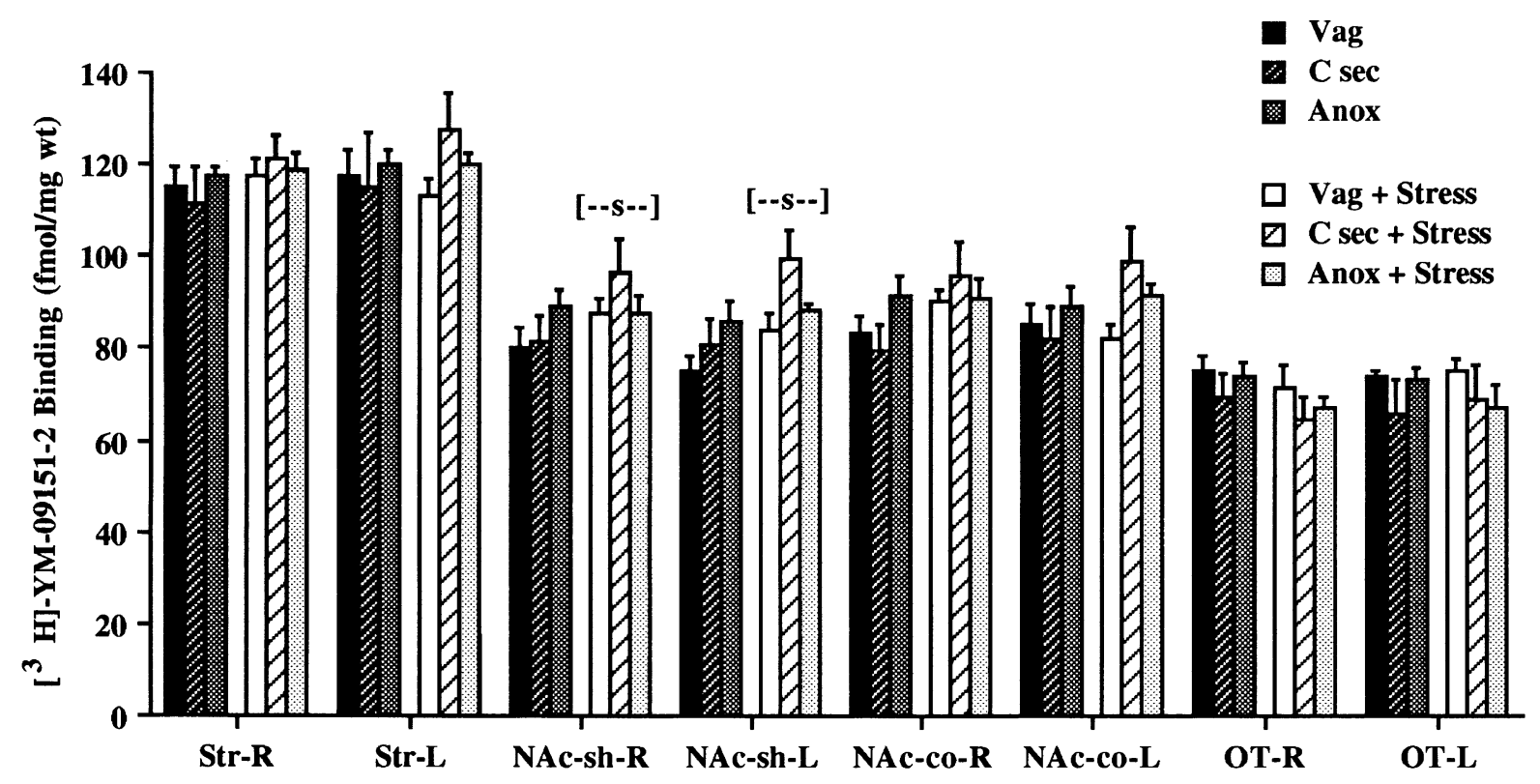

Figure 3. Quantitative autoradiographic assessment of D2-like DA receptors ([3H]-YM-09151-2) in brain regions of nonstressed and stressed adult rats, that had been born vaginally, by C-section or by C-section +15 min anoxia. Specific binding is expressed in $\mathrm{fmol} / \mathrm{mg}$ tissue and abbreviations used are as in Figure 1. Values shown represent the mean specific binding \pm SEM from the number of animals in parentheses as follows: Vag (7-8); C sec (6-7); Anox (7-8); Vag + Stress (8-10); C sec + Stress (8-9); Anox + Stress (9-10). [-s-] = different from the corresponding birth group with no stress at $p<.005$, due to main effect of stress across all birth groups. 

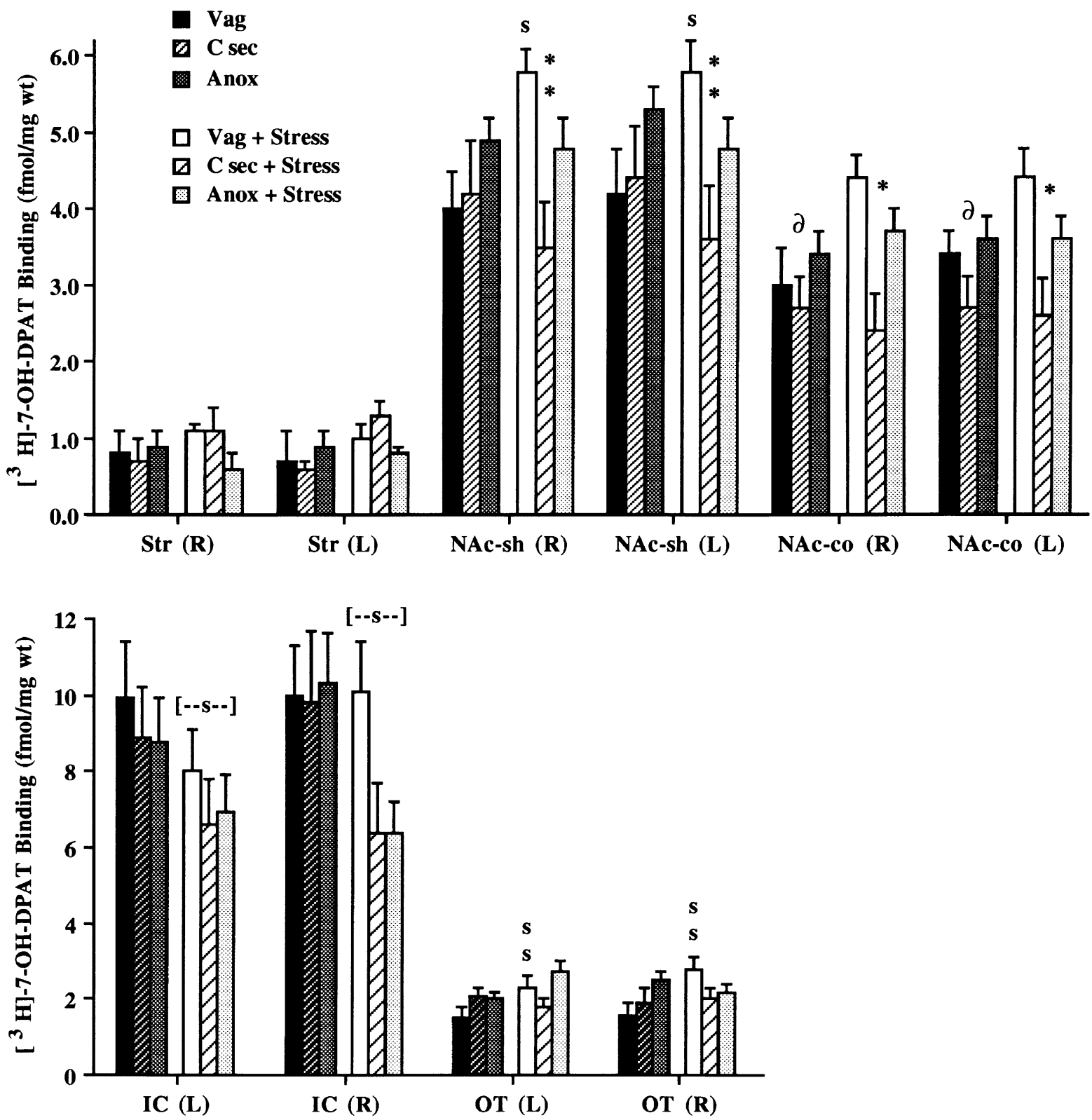

Figure 4. Quantitative autoradiographic assessment of D3 DA receptors ([3H]-7-OH-DPAT) in brain regions of nonstressed and stressed adult rats, that had been born vaginally, by C-section or by C-section +15 min anoxia. Specific binding is expressed in fmol/mg tissue and abbreviations used are as in Figure 1, with the addition of IC (islands of Calleja). Values shown represent the mean specific binding \pm SEM from the number of animals in parentheses as follows: Vag (7-9, with the exception of Str which was from 3-4); C sec (5-9); Anox (7-11); Vag + Stress (6-9); C sec + Stress (5-8); Anox + Stress (8-10). Note the different scales for the y axes in the upper and lower graphs. ${ }^{\mathrm{s}}=$ different from Vag (no stress) at $p<.05 ;{ }^{* *}$ different from Vag + Stress at $p<.01 ; \delta=$ different from both Vag and Anox at $p<.01$, due to main effect of birth group across stress/no stress; ${ }^{*}$ different from both Vag + Stress and Anox + Stress at $p<.01$, due to main effect of birth group across stress/no stress; [-s-] = different from the corresponding birth group with no stress at $p<.05$, due to main effect of stress across all birth groups; ${ }^{\text {ss }}=$ different from Vag (no stress) at $p<.005$.

groups, i.e., vaginal birth, C-section, and C-section + anoxia (Figure 1). Stress reduced D1-like receptor binding in additional brain regions, the infralimbic cortex and anterior olfactory nucleus, only in the $\mathrm{C}$-section group. As a result, stress reversed the increased D1-like receptor binding that was observed pre-stress in infralimbic cortex and anterior olfactory nucleus in C-sectioned animals relative to vaginal birth. Stress had no significant effect on D1-like receptor binding in dorsal striatum, NAcc or olfactory tubercles in any birth group (Figure 1). 


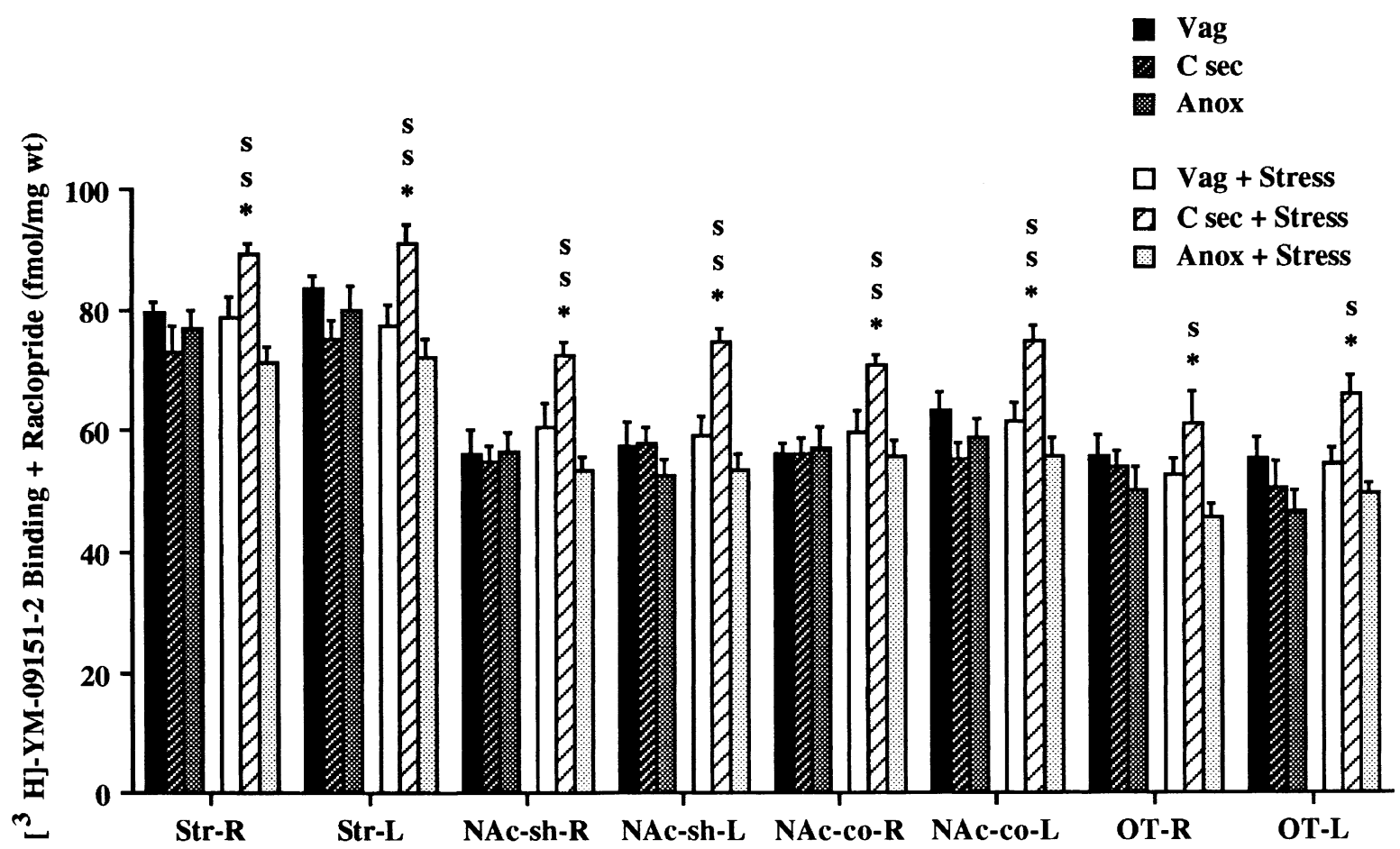

Figure 5. Quantitative autoradiographic assessment of D4-like DA receptors ([3H]-YM-09151-2 + raclopride) in brain regions of non-stressed and stressed adult rats, that had been born vaginally, by C-section, or by C-section +15 min anoxia. Specific binding is expressed in fmol/mg tissue and abbreviations used are as in Figure 1. Values shown represent the mean specific binding \pm SEM from the number of animals in parentheses as follows: Vag (8-9); C sec (8-9); Anox (8-9); Vag + Stress (7-10); C sec + Stress (7-9); Anox + Stress (8-9). * different from both Vag + Stress and Anox + Stress at $p<.01 ;$ ss $=$ different from $\mathrm{C} \mathrm{sec}$ (no stress) at $p<.001 ;{ }^{\mathrm{s}}=$ different from $\mathrm{C} \sec$ (no stress) at $p<.01$.

\section{Effects of Stress and Resulting Birth Group Differences after Stress: D2-like, D3, and D4-like Receptors}

D2-like receptor binding was assessed using [3H]-YM09151-2, which binds to the three members of the D2like receptor family, i.e., D2, D3, and D4 receptors. Repeated stress increased D2-like receptor binding in the NAcc shell in all birth groups, although the stress-induced increase in D2-like receptor binding was most prominent in the C-section group (Figure 3). Stress had no effect on D2-like binding in the dorsal striatum or olfactory tubercles in any birth group. After stress, there were no significant differences between birth groups in D2-like receptor binding in any brain region assessed.

Repeated stress significantly increased D3 receptor binding, measured using [3H]-7-OH-DPAT, in the NAcc shell and olfactory tubercles only in the vaginally born group but not in the other two birth groups (Figure 4). As a result, after stress D3 receptor binding was significantly lower in the $\mathrm{C}$-section group relative to vaginal birth in the NAcc shell (Figures 2c and 4). D3 receptor binding was also significantly lower in the NAcc core of C-sectioned animals compared to vaginal birth. Stress significantly reduced D3 receptor binding in the islands of Calleja in all birth groups. These changes in D3 receptor binding, obtained using $2 \mathrm{nM}[3 \mathrm{H}]-7-\mathrm{OH}-\mathrm{DPAT}$, are more consistent with changes in Bmax of the receptor rather than $\mathrm{Kd}$, since the $\mathrm{Kd}$ of D3 receptors for [3H]-7-OH-DPAT is in the range of $0.7-1.0 \mathrm{nM}$ (Lévesque et al. 1992).

Repeated stress significantly increased D4-like receptor binding, measured using [3H]-YM-09151-2 binding in the presence of raclopride, only in the C-sectioned group but not in other birth groups in the dorsal striatum, NAcc shell and core, and the olfactory tubercles (Figure 5). As a result, after stress D4-like receptor binding was significantly higher in the $\mathrm{C}$-section group relative to vaginal birth in all of these brain regions (Figures $2 \mathrm{~d}$ and 5).

\section{C-section + Anoxia Group}

Compared to vaginally born controls, animals born by C-section +15 min of anoxia showed no significant differences in levels of binding to D1-like, D2-like, D3, or D4-like receptors in any brain region, either before or after stress (Figures 1-5).

\section{DISCUSSION}

The main finding of this study is that there are long term alterations in DA receptors and their regulation by 
stress in rats born by C-section compared to vaginal birth. Previous work with inbred mouse strains suggested that genetic composition influences adaptation of DA receptors to stress (Puglisi-Allegra and Cabib 1997; Cabib et al. 1998). The present study indicates that an early environmental insult, namely C-section birth, can also lastingly influence adaptive responses of DA receptors to stress. Another major finding is that, in contrast to $\mathrm{C}$-sectioned animals, rats born by $\mathrm{C}$-section with 15 min of added global anoxia show no significant changes in DA receptor binding relative to vaginal birth, either before or after stress.

\section{D1-like Receptor Changes before Stress}

At baseline before stress, D1-like receptor binding was increased in limbic areas in C-sectioned compared to vaginally born animals. The mechanism responsible for this increase is not known. C-section may alter the normal developmental trajectory of D1-like receptors, which are present in rat brain at birth and increase progressively until adulthood (Murrin and Zeng 1990). This could further impact CNS development as D1 receptor activation decreases axonal and dendritic outgrowth in immature neurons (Reinoso et al. 1996).

Another mechanistic issue is whether increased D1like receptor binding after $\mathrm{C}$-section represents receptor upregulation in response to altered dopaminergic input. In adult rats, pharmacological reduction of DA input can induce upregulation of D1 receptors as evidenced by enhanced D1 receptor densities following chronic reserpine-induced DA depletion or chronic D1 receptor blockade (Joyce 1991; Giorgio et al. 1993). In contrast, DA denervation of the striatum by 6-hydroxydopamine in adult rats or mice decreases striatal D1 receptor binding and D1 mRNA levels (Marshall et al. 1989; LaHoste and Marshall, 1991; Qin et al. 1994). Thus, it has been argued that loss of DA input can upregulate D1 receptors while complete loss of DA fibers does not, because a trophic factor from DA fibers is necessary for D1 upregulation (LaHoste and Marshall 1991). Effects of dopaminergic lesioning in the neonatal animal appear to differ somewhat from effects of adult lesions. Reduction of DA innervation by intrastriatal 6hydroxydopamine lesion in rat pups on the day of birth (but not on postnatal day 7 or 15) results in adult animals showing significant reductions in neostriatal D1 receptor levels, coupled surprisingly, with increases in D1 mRNA (Frohna et al. 1995; Thomas et al. 1998). Therefore, it seems that D1 receptor metabolism is regulated in a complex manner when dopaminergic activity is reduced, with activation of DA receptors, integrity of DA fibers and age of the animal being important determinants of the response.

In contrast to effects of reduced dopaminergic activity, constitutive elevation of extracellular DA levels in mice, due to genetic deletion of the dopamine transporter
(DAT) from conception, has been reported to decrease D1 and D2 receptor mRNA and increase D3 receptor mRNA, although levels of receptor protein or binding were not reported (Fauchey et al. 2000). Thus, it appears likely that a long term increase in extracellular DA, as seen in the DAT knockout, might alter levels of several subtypes of DA receptors, in contrast to the selective change in D1 receptors seen in C-sectioned rats.

At a behavioral level, adult rats born by C-section show increased amphetamine-induced locomotion and other behavioral responses, compared to vaginally born animals (El-Khodor and Boksa 1998). Background evidence suggests that the increased NAcc D1 receptors found in C-sectioned animals could play a role in producing this enhanced locomotion. For example, intraNacc injections of D1 agonists, or of D1 and D2 agonists together, increase locomotion in the rat (Dreher and Jackson 1989). In addition, when DA function is sensitized by repeated psychostimulant administration, NAcc D1 receptors are electrophysiologically more responsive, whereas D1 antagonists prevent enhanced DA-mediated locomotion in sensitized rats (Pierce and Kalivas 1997). Similarly, rat subpopulations exhibiting increased novelty-induced and DA-induced locomotion show increased NAcc D1 receptors (Hooks et al. 1994). Increased D1 receptors in NAcc could similarly contribute to enhanced motor responses seen after C-section. However, D1 receptors in infralimbic cortex can inhibit NAcc DA release and DA-mediated locomotion (Vezina et al. 1991; Doherty and Gratton 1996), thus increased infralimbic and NAcc D1 receptors in C-sectioned animals might have opposing effects. Additionally, since NAcc D1 receptors were unchanged in rats born by C-section + anoxia, other mechanisms (e.g., changes in the DA transporter or in DA receptor transduction) must account for enhanced amphetamine-induced behavioral responses observed in this group (El-Khodor and Boksa 1998).

\section{Effects of Stress on DA Receptors}

Although stress clearly activates DA transmission (Brake et al. 1997b; Puglisi-Allegra and Cabib 1997; Sullivan and Gratton 1998), few studies have examined effects of stress on DA receptors and to our knowledge none examined stress effects on D3 and D4-like receptors. In vaginally born control rats, repeated tail pinch stress decreased D1-like receptor binding in lateral frontal and cingulate cortices and increased D2-like receptors in NAcc shell. In C-sectioned animals stress had similar effects and additionally decreased D1-like receptor binding in infralimbic cortex and olfactory nucleus. Most notably, vaginally born controls showed stress-induced increases in NAcc D3 receptors and no change in D4-like receptors while C-sectioned animals showed no stress-induced changes in D3 receptors but increased D4-like receptors in NAcc and dorsal stria- 
tum. These effects were present at two weeks after the final stress.

Our laboratory has demonstrated that C-sectioned rats show marked enhancement of NAcc DA release following repeated tail pinch stress, while vaginally born controls do not (Brake et al. 1997b). The lack of stress-induced upregulation of NAcc D3 receptors in the $\mathrm{C}$-sectioned group may represent a molecular mechanism for their enhanced stress-induced DA release, since there is evidence that D3 receptors may inhibit DA release and synthesis (Tang et al. 1994; Rivet et al. 1994; Nissbrandt et al. 1995; DeBoer et al. 1997). The function of D4 receptors is not yet clear, although they do not appear to regulate DA release (Tang et al. 1994).

In previous studies examining stress effects on DA receptors in rats, restraint stress for 12 days decreased NAcc D1 receptors with no effect on D2-like receptors (Giardino et al. 1998). Varied mild stress for 8 weeks increased D1 receptors in striatum and decreased D2-like receptors in limbic forebrain (Papp et al. 1994), while food deprivation for 7-10 days had no effect on D1-like or D2-like receptors (Pothos et al. 1995). Thus different stress paradigms may differentially affect DA receptors.

\section{Possible Mechanisms by Which C-section Birth and Global Anoxia Affect DA Receptor Regulation}

How C-section birth alters DA receptor regulation, and why $15 \mathrm{~min}$ of global anoxia, perhaps somewhat surprisingly, prevents these changes are not known. However two factors, i.e., plasma hormone levels and the extent of hypoxia at birth, could play a role. First, vaginal birth stimulates marked increases in neonatal levels of many plasma hormones, including catecholamines, glucocorticoids, vasopressin, neuropeptide $\mathrm{Y}$, endorphin, somatostatin, adenosine, and prostaglandins (Lagercrantz 1994). Catecholamines and glucocorticoids protect against hypoxia and adapt the neonate to extrauterine life by promoting lung maturation and other mechanisms, while the roles of other hormonal surges are undetermined. Plasma catecholamines and glucocorticoids at birth are much reduced in rats (and humans) born by C-section compared to vaginal birth (Lagercrantz 1994; Boksa 1997; El-Khodor and Boksa 1997) and this deficiency might alter CNS development. By contrast, birth hypoxia potently stimulates catecholamine secretion, and plasma epinephrine levels at birth are much higher in rats after C-section +15 min anoxia compared to vaginal birth (Lagercrantz 1994; ElKhodor and Boksa 1997). Thus, reversal of hormonal deficiencies at birth by the stimulus of global anoxia may contribute towards maintaining normal DA receptor profiles in the $\mathrm{C}$-section + anoxia group.

Second, in C-sectioned rats, systemic oxygenation and brain energy stores are well-maintained at birth, but later during the first $24 \mathrm{~h}$ of life, respiratory rates are altered and brain lactate slightly increased (ElKhodor and Boksa 1997; Vaillancourt et al. 1999). Thus, very low grade hypoxia after C-section birth could contribute to later CNS changes. This parallels reports of increased mild respiratory distress in humans following C-section vs. vaginal birth (Hales et al. 1993). It is important to note, however, that adult rats born by the current $\mathrm{C}$-section procedure perform normally in a wide range of behavioral tests (Boksa et al. 1995, 1998) and, therefore, are not generally impaired. Rats born by C-section +10 min global anoxia show reduced brain ATP and increased brain lactate at birth, indicative of CNS hypoxia. However, global anoxia activates compensatory ventilatory responses, so anoxic pups actually have higher systemic pO2 than do C-sectioned pups at $<30 \mathrm{sec}$ after birth, and no evidence of subsequent respiratory distress (El-Khodor and Boksa 1997; Berger et al. 2000). Thus, it appears that pups undergoing a short period of global anoxia during C-section birth show more rapid and lasting respiratory adaptation than do C-sectioned animals.

\section{Other Perinatal Insults and DA Receptors}

Long term changes in DA receptors have been observed following other perinatal insults. Prenatal stress enhances DA-mediated behavior, increases NAcc D2 receptors and decreases NAcc D3 receptors in adult rats (Henry et al. 1995). Neonatal rats receiving ventral hippocampal lesions show enhanced DA-mediated behavior, as adults (Lipska et al. 1993; Flores et al. 1996a; Black et al. 1998; Schroeder et al. 1999). Four studies examining DA receptors in this lesion model have reported a slight increase in striatal D1 receptor binding, no change in D2 receptors, and decreased NAcc D3 receptors (Flores et al. 1996a), no change in striatal D2 receptor binding (Black et al. 1998), no change in Nacc, striatal D1, or D2/3 receptor binding (Lillrank et al. 1999), and decreases in striatal D1 and D2 receptor binding (Schroeder et al. 1999). These studies support the idea that subtle factors associated with perinatal insult may affect DA receptor density in the long term.

Chen et al. (1997b) have also measured DA receptors in (non-stressed, prepubertal 4 week old) rats born by $\mathrm{C}$-section with global hypoxia. Their study did not include a vaginally born control group, however consistent with the present results NAcc [3H]-SCH-23390 binding was increased and D2 antagonist binding unchanged in C-sectioned animals compared to C-section + 15 min anoxia.

\section{Comparison to Humans}

It is of interest to compare DA receptor changes in the C-sectioned rat model with those reported in schizophrenia. Decreases or no change in D1 receptors in pre- 
frontal cortex have been reported in schizophrenic subjects (Knable et al. 1996; Okubo et al. 1997), whereas a recent meta-analysis of imaging studies detected a mild elevation of striatal D2 receptors in schizophrenia vs. controls (Laruelle 1998). Two recent meta-analyses concluded that schizophrenia is associated with increased homozygosity for a Bal I D3 receptor polymorphism (Dubertret et al. 1998; Williams et al. 1998). It is unknown if this form of the D3 receptor is fully functional. Decreased D3 function in schizophrenia is supported by the observations of decreased D3 mRNA in schizophrenia due to abnormal splicing of D3 pre-mRNA (Schmauss et al. 1993; Schmauss 1996), and worsening of psychotic symptoms in schizophrenic subjects given a D3-preferring antagonist (Lahti et al. 1998b). However, Gurevich et al. (1997) reported increased D3 receptor binding in limbic striatum of medication free schizophrenic subjects. Several studies report increased striatal D4-like receptor binding in schizophrenia, including one using a recently developed D4-preferring radioligand (Lahti et al. 1998a; Marzella et al. 1997; see review by Sanyal and Van Tol 1997; but see Helmeste et al. 1996).

In comparison to the profile in schizophrenia, repeatedly stressed C-sectioned rats showed no change in D1like receptors, a tendency to increased D2-like receptor binding, decreased D3 and increased D4-like receptors in the NAcc, relative to vaginally born controls. Although the DA receptor profile observed in C-sectioned rats after stress bears some similarity to the pattern seen in schizophrenia, there are many caveats to comparing these animal with human studies. For instance, reported changes in DA receptors in schizophrenia are not entirely consistent across studies due, likely, to a multitude of factors inherent in human studies (e.g., heterogeneity of schizophrenia, medication status, chronicity, etc). Animal studies indicate that different experimental stress paradigms may differentially alter DA receptors, thus the particular pattern of life stress experienced by the individual (animal or human) will also likely influence DA receptor patterns.

In relation to human development, it should also be emphasized that there are important differences in the $\mathrm{C}$-section procedure used in rats in this study and human C-section birth. For example, C-section birth was from a decapitated rat dam to avoid the confound of anesthetic effects. Anesthetics used in human C-section can depress respiratory function and compensatory responses to birth hypoxia, while also promoting neuroprotection by depressing cerebral metabolism (Newberg and Michenfelder 1983; Berger et al. 2000). In this context, our recent studies have demonstrated that rats born by C-section from isoflurane/nitrous oxide anesthetized (rather than decapitated) dams also show enhanced amphetamine-induced locomotion as adults, compared to vaginally born control rats (Vaillancourt and Boksa 1998). It should also be recalled that the rat brain at birth is at a less mature developmental stage than is the brain of the human neonate (Romijn et al. 1991). Thus, the rat model of C-section birth may relate more to the condition of the premature rather than the term human infant. However, we have recently demonstrated that $\mathrm{C}$-section birth also produces long-term enhancement of amphetamine-induced locomotion in the guinea pig (Vaillancourt and Boksa 2000), a species whose CNS is more mature at birth than is the human. Thus, although not mimicking human C-section in every aspect, the rat model of $\mathrm{C}$-section birth is of value to investigate specific factors and mechanisms inherent in the C-section procedure (e.g., prolonged mild hypoxia neonatally, lack of hormonal surges at birth) that may be critical for altering dopaminergic function in the long term. Such mechanisms may have relevance to schizophrenia, a disorder associated with increased birth complications, exacerbation of symptoms by stress and altered dopaminergic function.

\section{CONCLUSIONS}

This study indicates that DA receptors and their modulation by stress are susceptible to alteration by seemingly subtle changes in birth procedure in the rat. The differential effects of stress on DA receptors in the various birth groups indicate that the individual's previous experience of stress together with other environmental events in their history, such as birth complications, will be important in determining DA receptor levels. These factors could also be important in studies of human DA receptor levels.

\section{ACKNOWLEDGMENTS}

This work was supported by a grant to P.B. from the Canadian Institutes of Health Research (formerly Medical Research Council of Canada) and a studentship to B. El-K. from Fonds pour la Formation de Chercheurs et l'Aide à la Recherche / Fonds de la Recherche en Santé du Québec. We thank Drs. Lalit Srivastava, Gonzalo Flores, and Rémi Quirion for helpful discussion and comments on the manuscript.

\section{REFERENCES}

Accili D, Fishburn CS, Drago J, Steiner H, Lachowicz JE, Park BH, Gauda EB, Lee EJ, Cool MH, Sibley DR, Gerfen CR, Westphal H, Fuchs S (1996): A targeted mutation of the D3 dopamine receptor gene is associated with hyperactivity in mice. Proc Natl Acad Sci U S A 93:1945-1949

Benes FM (1997): The role of stress and dopamine-GABA interactions in the vulnerability for schizophrenia. J Psychiatr Res 31:257-275 
Berger N, Vaillancourt C, Boksa P (2000): Interactive effects of anoxia and general anesthesia during birth on the degree of CNS and systemic hypoxia produced in neonatal rats. Exp Brain Res 131:524-531

Bjelke B, Andersson K, Ögren SÖ, Bolme P (1991): Asphytic lesion: proliferation of tyrosine hydroxylase immunoreactive nerve cell bodies in the rat substantia nigra and functional changes in dopamine neurotransmission. Brain Res 543:1-9

Black MD, Lister S, Hitchcock JM, Van Giersbergen P, Sorensen SM (1998): Neonatal hippocampal lesion model of schizophrenia in rats: Sex differences and persistence of effects into maturity. Drug Dev Res 43:206213

Boksa P, Krishnamurthy A, Brooks W (1995): Effects of a period of asphyxia during birth on spatial learning in the rat. Pediatr Res. 37:489-496

Boksa P (1997): Early developmental profiles of plasma corticosterone are altered by birth condition in the rat: A comparison of vaginal birth, Caesarean section and Caesarean section with added anoxia. Pediatric Res 41:34-43

Boksa P, Wilson D, Rochford J (1998): Responses to stress and novelty in adult rats born vaginally, by Caesarean section or by Caesarean section with acute anoxia. Biol Neonate 74:48-59

Brake WG, Boksa P, Gratton A (1997a): Effects of perinatal anoxia on the acute locomotor response to repeated amphetamine administration in adult rats. Psychopharmacology 133:389-395

Brake WG, Noel MB, Boksa P, Gratton A (1997b): Influence of perinatal factors on the nucleus accumbens dopamine response to repeated stress during adulthood: An electrochemical study in rat. Neuroscience 77:1067-1076

Braun AR, Chase TN (1986): Obligatory D-1 / D-2 receptor interaction in the generation of dopamine agonist related behaviors. Eur J Pharmacol 131:301-306

Breier A, Su T-P, Saunders R, Carson RE, Kolachana BS, de Bartolomeis A, Weinberger DR, Weisenfeld N, Malhotra AK, Eckelman WC, Pickar D (1997): Schizophrenia is associated with elevated amphetamine-induced synaptic dopamine concentrations: Evidence from a novel positron emission tomography method. Proc Natl Acad Sci U S A 94:2569-2574

Cabib S, Giardino L, Calzá L, Zanni M, Mele A, PuglisiAllegra S (1998): Stress promotes major changes in dopamine receptor densities within the mesoaccumbens and nigrostriatal systems. Neuroscience 84:193200

Chen Y, Ögren SO, Bjelke B, Bolme P, Eneroth P, Gross J, Loidl F, Herrera-Marschitz M, Andersson K (1995): Nicotine treatment counteracts perinatal asphyxia-induced changes in the mesostriatal/limbic dopamine systems and in motor behavior in the four-week-old male rat. Neuroscience 68:531-538

Chen Y, Engidawork E, Loidl F, Dell'Anna E, Goiny M, Lubec G, Andersson K, Herrera-Marschitz M (1997a): Short- and long-term effects of perinatal asphyxia on monoamine, amino acid and glycolysis product levels measured in the basal ganglia of the rat. Dev Brain Res 104:19-30
Chen Y, Hillefors-Berglund M, Herrera-Marschitz M, Bjelke B, Gross J, Andersson K, von Euler G (1997b): Perinatal asphyxia induces long-term changes in dopamine D1, D2 and D3 receptor binding in the rat brain. Exp Neurol 146:74-80

Dalman C, Allebeck P, Cullberg J, Grunewald C, Köster M (1999): Obstetric complications and the risk of schizophrenia: A longitudinal study of a national birth cohort. Arch Gen Psychiatry 56:234-240

Dawson TM, Gehlert DR, McCabe RT, Barnett A, Wamsley JK (1986): D-1 dopamine receptors in the rat brain: A quantitative autoradiographic analysis. J Neurosci 6: 2352-2365

De Boer P, Enrico P, Wright J, Wise LD, Timmerman W, Moor E, Dijkstra D, Wikström HV, Westerink BHC (1997): Characterization of the effect of dopamine D3 receptor stimulation on locomotion and striatal dopamine levels. Brain Res 758:83-91

Demotes-Mainard J, Henry C, Jeantet Y, Arsaut J, Arnauld E (1996): Postnatal ontogeny of dopamine D3 receptors in the mouse brain: Autoradiographic evidence for a transient cortical expression. Dev Brain Res 94:166-174

Doherty M, Gratton A (1996): Medial prefrontal cortical D1 receptor modulation of the meso-accumbens dopamine response to stress: An electrochemical study in freely behaving rats. Brain Res 715:86-97

Dreher JK, Jackson DM (1989): Role of D1 and D2 dopamine receptors in mediating locomotor activity elicited from the nucleus accumbens of rats. Brain Res 487:267-277

Dubertret C, Gorwood P, Ades J, Feingold J, Schwartz JC, Sokoloff P (1998): Meta-analysis of DRD3 gene and schizophrenia: Ethnic heterogeneity and significant association in Caucasians. Am J Med Genet 81:318-322

El-Khodor BF, Boksa P (1997): Long-term reciprocal changes in dopamine levels in prefrontal cortex versus nucleus accumbens in rats born by Caesarean section compared to vaginal birth. Exp Neurol 145:118-129

El-Khodor BF, Boksa P (1998): Birth insult increases amphetamine-induced behavioral responses in the adult rat. Neuroscience 87:893-904

Fauchey V, Jaber M, Caron MG, Bloch B, Le Moine C (2000): Differential regulation of the dopamine D1, D2 and D3 receptor gene expression and changes in the phenotype of the striatal neurons in mice lacking the dopamine transporter. Eur J Neurosci 12:19-26

Flores G, Barbeau D, Quirion R, Srivastava LK (1996a): Decreased binding of dopamine D3 receptors in limbic subregions after neonatal bilateral lesion of rat hippocampus. J Neurosci 16:2020-2026

Flores G, Wood GK, Liang J-J, Quirion R, Srivastava LK (1996b): Enhanced amphetamine sensitivity and increased expression of dopamine D2 receptors in postpubertal rats after neonatal excitotoxic lesions of the medial prefrontal cortex. J Neurosci 16:7366-7375

Frohna PA, Neal-Beliveau BS, Joyce JN (1995) : Neonatal 6-hydroxydopamine lesions lead to opposing changes in the levels of dopamine receptors and their messenger RNAs. Neuroscience 68:505-518

Geddes JR, Verdoux H, Takei N, Lawrie SM, Bovet P, Eagles JM, Heun R, McCreadie RG, McNeil TF, O'Callaghan E, Stober G, Willinger U, Murray RM (1999): Schizophre- 
nia and complications of pregnancy and labor: and individual patient meta-analysis. Schizophr Bull 25:413-423

Giardino L, Zanni M, Pozza M, Betelli C, Covelli V (1998): Dopamine receptors in the striatum of rats exposed to repeated restraint stress and alprazolam treatment. Eur J Pharmacol 344:143-147

Giorgio O, Pibiri MG, Loi R, Corda MG (1993): Chronic treatment with SCH 23390 increases the production rate of dopamine D1 receptors in the nigro-striatal system of the rat. Eur J Pharmacol 245:139-145

Goldsmith SK, Shapiro RM, Joyce JN (1997): Disrupted pattern of D2 dopamine receptors in the temporal lobe in schizophrenia: A postmortem study. Arch Gen Psychiatry 54:649-658

Gurevich EV, Bordelon Y, Shapiro RM, Arnold SE, Gur RE, Joyce JN (1997): Mesolimbic dopamine D3 receptors and use of antipsychotics in patients with schizophrenia. Arch Gen Psychiatry 54:225-232

Hales KA, Morgan MA, Thurnau GR (1993): Influence of labor and route of delivery on the frequency of respiratory morbidity in term neonates. Int J Gynecol Obstet 43: $35-40$

Helmeste DM, Tang SW, Bunney WE Jr, Potkin SG, Jones EG (1996): Decrease in sigma but no increase in striatal dopamine D4 sites in schizophrenic brains. Eur J Pharmacol 314:R3-R5

Henry C, Guegant G, Cador M, Arnauld E, Arsaut J, Le Moal M, Demotes-Mainard J (1995): Prenatal stress facilitates amphetamine-induced sensitization and induces longlasting changes in dopamine receptors in the nucleus accumbens. Brain Res 685:179-186

Hooks MS, Juncos JL, Justice JB Jr, Meiergerd SM, Povlock SL, Schenk JO, Kalivas PW (1994): Individual locomotor response to novelty predicts selective alterations in D1 and D2 receptors and mRNAs. J Neurosci 14:6144-6152

Jilek L, Travnickova E, Trojan S (1970): Characteristic metabolic and functional responses to oxygen deficiency in the central nervous system. In Stave U (ed), Physiology of the Perinatal Period, vol. 2. Functional and Biochemical Development in Mammals. New York, AppletonCentury Crofts, Meredith Corp, pp 987-1041

Jones PB, Rantakallio P, Hartikainen A-L, Isohanni M, Sipila $P$ (1998): Schizophrenia as a long-term outcome of pregnancy, delivery and perinatal complications: A 28 year follow-up of the 1966 North Finland general population cohort. Am J Psychiatry 155:355-364

Joyce JN (1991): Differential response of striatal dopamine and muscarinic cholinergic receptor subtypes to the loss of dopamine. II. Effects of 6-hydroxydopamine or colchicine microinjections into the VTA or reserpine treatment. Exp Neurol 113:277-290

Kalivas PW, Stewart J (1991): Dopamine transmission in the initiation and expression of drug- and stress-induced sensitization of motor activity. Brain Res Rev 16:223-244

Knable MB, Hyde TM, Murray AM, Herman MM, Kleinman JE (1996): A postmortem study of frontal cortical dopamine D1 receptors in schizophrenics, psychiatric controls and normal controls. Biol Psychiatry 40:1191-1199

Lachowicz JE, Sibley DR (1997): Molecular characteristics of mammalian dopamine receptors. Pharmacol Toxicol 81:105-113
Lagercrantz H (1994): Excitation of the sympatho-adrenal system at birth. In Amiel-Tison C, Stewart A (eds), The Newborn Infant, One Brain for Life. Paris, Les Editions INSERM, pp 57-66

LaHoste GJ, Marshall JF (1991): Chronic eticlopride and dopamine denervation induce equal nonadditive increases in striatal D2 receptor density: Autoradiographic evidence against the dual mechanism hypothesis. Neuroscience 41:473-481

Lahti RA, Roberts RC, Cochrane EV, Primus RJ, Gallager DW, Conley RR, Tamminga CA (1998a): Direct determination of dopamine $\mathrm{D} 4$ receptors in normal and schizophrenic postmortem brain tissue: A [3H]NGD-94-1 study. Molec Psychiatry 3:528-533

Lahti RA, Weiler M, Carlsson A, Tamminga CA (1998b): Effects of the D3 and autoreceptor-preferring dopamine antagonist (+)-UH232 in schizophrenia. J Neural Transm 105:719-734

Laruelle M, Abi-Dargham A, van Dyck CH, Gil R, D'Souza $\mathrm{CD}$, Erdos J, McCance E, Rosenblatt W, Fingado C, Zoghbi SS, Baldwin RM, Seibyl JP, Krystal JH, Charney DS, Innis RB (1996): Single photon emission computerized tomography imaging of amphetamine-induced dopamine release in drug-free schizophrenic subjects. Proc Natl Acad Sci U S A 93:9235-9240

Laruelle M (1998): Imaging dopamine neurotransmission in schizophrenia. A review and meta-analysis. Q J Nucl Med 42:211-221

Laruelle M, Abi-Dargham A, Gil R, Kegeles L, Innis RB (1999): Increased dopamine transmission in schizophrenia: Relationship to illness phase. Biol Psychiatry 46:56-72

Lévesque D, Diaz J, Pilon C, Martres MP, Giros B, Souil B, Schott D, Morgat JL, Schwartz JC (1992): Identification, characterization and localization of the dopamine D3 receptor in the rat brain using 7-[3H]hydroxy-N-N-din-propyl-2-aminotetralin. Proc Natl Acad Sci U S A 89:8155-8159

Lieberman JA, Sheitman BB, Kinon BJ (1997): Neurochemical sensitization in the pathophysiology of schizophrenia: Deficits and dysfunction in neuronal regulation and plasticity. Neuropsychopharmacology 17:205-229

Lillrank SM, Lipska BK, Weinberger DR, Fredholm BB, Fuxe K, Ferre S (1999): Adenosine and dopamine receptor antagonist binding in the ventral and dorsal striatum: Lack of changes after a neonatal bilateral lesion of the ventral hippocampus. Neurochem Int 34:235-244

Lipska BK, Jaskiw GE, Weinberger DR (1993): Postpubertal emergence of hyperresponsiveness to stress and to amphetamine after neonatal excitotoxic hippocampal damage: A potential animal model of schizophrenia. Neuropsychopharmacology 9:67-75

Loidl CF, Herrera-Marschitz M, Andersson K, You Z-B, Goiny M, O'Connor WT, Silveira R, Rawal R, Bjelke B, Chen Y, Ungerstedt U (1994): Long-term effects of perinatal asphyxia on basal ganglia neurotransmitter systems studied with microdialysis in rat. Neurosci Lett 175:9-12

Marshall JF, Navarrete R, Joyce JN (1989): Decreased striatal D1 binding density following mesotelencephalic 6-hydroxydopamine injections: An autoradiographic analysis. Brain Res 493:247-257 
Marzella PL, Hill C, Keks N, Singh B, Copolov D (1997): The binding of both $[3 \mathrm{H}]$ nemonapride and $[3 \mathrm{H}]$ raclopride is increased in schizophrenia. Biol Psychiatry 42:648-654

McNeil TF (1995): Perinatal risk factors and schizophrenia: Selective review and methodological concerns. Epidemiol Rev 17:107-112

Murrin LC, Zeng W (1990): Ontogeny of dopamine D1 receptors in rat forebrain: A quantitative autoradiographic study. Dev Brain Res 57:7-13

Newberg LA, Michenfelder JD (1983): Cerebral protection by isoflurane during hypoxia or ischemia. Anesthesiology 59:29-35

Nissbrandt H, Ekman A, Eriksson E, Heilig M (1995): Dopamine D3 receptor antisense influences dopamine synthesis in rat brain. Neuroreport 6:573-576

Okubo Y, Suhara T, Suzuki K, Kobayashi K, Inoue O, Terasaki O, Someya Y, Sassa T, Sudo Y, Matsushima E, Iyo M, Tateno Y, Toru M (1997): Decreased prefrontal dopamine D1 receptors in schizophrenia revealed by PET. Nature 385:634-636

Papp M, Klimek V, Willner P (1994): Parallel changes in dopamine D2 receptor binding in limbic forebrain associated with chronic mild stress-induced anhedonia and its reversal by imipramine. Psychopharmacology 115: $441-446$

Paxinos G, Watson C (1986): The rat brain in stereotaxic coordinates, 2nd ed. San Diego, Academic Press

Pierce RC, Kalivas PW (1997): A circuitry model of the expression of behavioral sensitization to amphetaminelike psychostimulants. Brain Res Rev 25:192-216

Pothos EN, Creese I, Hoebel BG (1995): Restricted eating with weight loss selectively decreases extracellular dopamine in the nucleus accumbens and alters dopamine response to amphetamine, morphine, and food intake. J Neurosci 15:6640-6650

Primus RJ, Thurkauf A, Xu J, Yevich E, McInerey S, Shaw K, Tallman JF, Gallagher DW (1997): Localization and characterization of dopamine D4 binding sites in rat and human brain by use of the novel D4 receptor-selective ligand [3H]NGD 94-1. J Pharmacol Exp Ther 282:1020-1027

Puglisi-Allegra S, Cabib S (1997): Psychopharmacology of dopamine: The contribution of comparative studies in inbred strains of mice. Progr Neurobiol 51:637-661

Qin Z-H, Chen JF, Weiss B (1994): Lesions of mouse striatum induced by 6-hydroxydopamine differentially alter the density, rate of synthesis, and level of gene expression of D1 and D2 dopamine receptors. J Neurochem 62:411420

Reinoso BS, Undie AS, Levitt P (1996): Dopamine receptors mediate differential morphological effects on cerebral cortical neurons in vitro. J Neurosci Res 43:439-453

Rivet JM, Audinot V, Gobert A, Peglion JL, Millan MJ (1994): Modulation of mesolimbic dopamine release by the selective dopamine D3 receptor antagonist, (+)-S14297. Eur J Pharmacol 265:175-177

Romijn HH, Hofman MA, Gramsbergen A (1991): At what age is developing rat cortex comparable to that of the full term human baby? Early Human Dev 26:61-67

Rosso M, Cannon TD, Huttunen T, Huttunen MO, Lönn- qvist J, Gasperoni T (2000): Obstetric risk factors for early-onset schizophrenia in a Finnish birth cohort. Am J Psychiatry 157:801-807

Sanyal S, Van Tol HHM (1997): Review of the role of dopamine D4 receptors in schizophrenia and antipsychotic action. J Psychiatr Res 31:219-232

Schmauss C, Haroutunian V, Davis KL, Davidson M (1993): Selective loss of dopamine D3-type receptor mRNA expression in parietal and motor cortices of patients with chronic schizophrenia. Proc Natl Acad Sci U S A 90:8942-8946

Schmauss C (1996): Enhanced cleavage of an atypical intron of dopamine D3-receptor pre-mRNA in chronic schizophrenia. J Neurosci 16:7902-7909

Schroeder H, Grecksch G, Becker A, Bogerts B, Hoelt V (1999): Alterations of the dopaminergic and glutamatergic neurotransmission in adult rats with postnatal ibotenic acid hippocampal lesion. Psychopharmacology 145:61-66

Seeman P (1992): Dopamine receptor sequences: therapeutic levels of neuroleptics occupy D2 receptors, clozapine occupies D4. Neuropsychopharmacology 7:261-284

Sullivan RM, Gratton A (1998): Relationships between stress-induced increases in medial prefrontal cortical dopamine and plasma corticosterone levels in rats: role of cerebral laterality. Neuroscience 83:81-91

Tang L, Todd RD, O'Malley KL (1994): Dopamine D2 and D3 receptors inhibit dopamine release. J Pharmacol Exp Ther 270:475-479

Tarazi FI, Kula NS, Baldessarini RJ (1997): Regional distribution of dopamine D4 receptors in rat forebrain. Neuroreport 10:3423-3426

Thomas WS, Neal-Beliveau BS, Joyce JN (1998): There is a limited critical period for dopamine's effects on D1 receptor expression in the developing striatum. Dev Brain Res 111:99-106

Vaillancourt C, Berger N, Boksa P (1999): Effects of vaginal birth versus Caesarean section birth with general anesthesia on blood gases and brain energy metabolism in neonatal rats. Exp Neurol 160:142-150

Vaillancourt C, Boksa P (1998): Caesarean section birth with general anesthesia increases dopamine-mediated behavior in the adult rat. Neuroreport 9:2953-2959

Vaillancourt C, Boksa P (2000): Birth insult alters dopaminemediated behavior in a precocial species, the guinea pig: Implications for schizophrenia. Neuropsychopharmacology 23:654-666

Vezina P, Blanc G, Glowinski J, Tassin JP (1991): Opposed behavioral outputs of increased dopamine transmission in prefrontocortical and subcortical areas: A role for cortical D1 receptor. Eur J Neurosci 3:1001-1007

Waddington JL, Scully PJ, O'Callaghan E (1998): Neurodevelopmental and neuroprogressive processes in schizophrenia: Antithetical or complementary, over a lifetime trajectory of disease? Psychiatr Clin North Am 21:123149

Walker EF, Neumann CC, Baum K, Davis DM, DiForio, Bergman A (1996): The developmental pathways to schizophrenia: Potential moderating effects of stress. Dev Psychopathol 8:647-665 
Weinberger DR (1995): Neurodevelopmental perspectives on schizophrenia. In Bloom FE, Kupfer DJ (eds), Psychopharmacology: the Fourth Generation of Progress. New York, Raven Press Ltd, pp 1171-1183

Williams J, Spurlock G, Holmans P, Mant R, Murphy K, Jones L, Cardno A, Asherson P, Blackwood D, Muir W, Meszaros K, Aschauer H, Mallet J, Laurent C, Pekkarinen $\mathrm{P}$, Seppala J, Stefanis CN, Papadimitriou GN, Macciardi F, Verga M, Pato C, Azevedo H, Crocq MA, Gurling H, Owen MJ (1998): A meta-analysis and transmission dise- quilibrium study of association between the dopamine D3 receptor gene and schizophrenia. Molec Psychiatry 3:141-149

Wolf ME, Roth RH (1990): Autoreceptor regulation of dopamine synthesis. Ann N Y Acad Sci 604:323-343

Zornberg GL, Buka SL, Tsuang MT (2000): Hypoxicischemia-related fetal/neonatal complications and risk of schizophrenia and other non-affective psychoses: A 19-year longitudinal study. Am J Psychiatry 157:196-202 